Prepared in cooperation with the CITY OF WICHITA, KANSAS

\title{
Status of Ground-Water Levels and Storage in the Wichita Well Field Area, South-Central Kansas, 1997
}

Water-Resources Investigations 98-4095
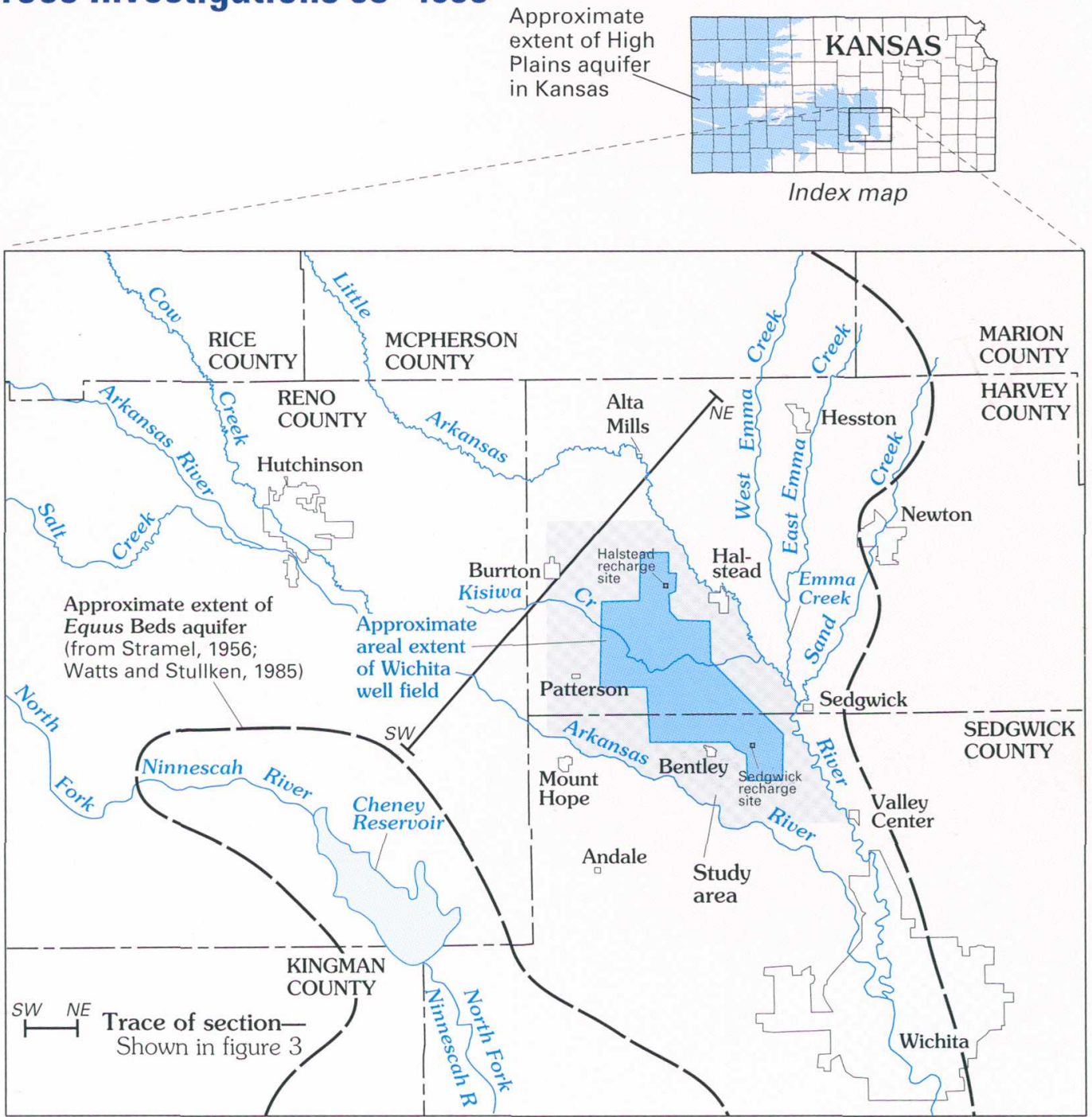
Prepared in cooperation with the CITY OF WICHITA, KANSAS

\section{Status of Ground-Water Levels and Storage in the Wichita Well Field Area, South-Central Kansas, 1997}

By WALTER R. AUCOTT, NATHAN C. MYERS, and BARBARA J. DAGUE

Water-Resources Investigations Report 98-4095

Lawrence, Kansas

1998 


\section{U.S. Department of the Interior}

Bruce Babbitt, Secretary

\section{U.S. Geological Survey}

Thomas J. Casadevall, Acting Director

For additional information write to:

District Chief

U.S. Geological Survey

4821 Quail Crest Place

Lawrence, KS 66049-3839
Copies of this report can be purchased from:

U.S. Geological Survey

Information Services

Box 25286

Federal Center

Denver, CO 80225-0826 


\section{CONTENTS}

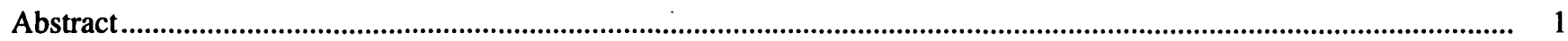

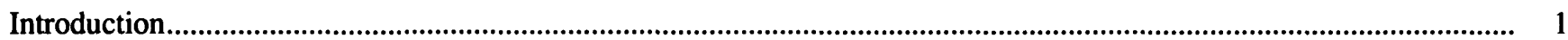

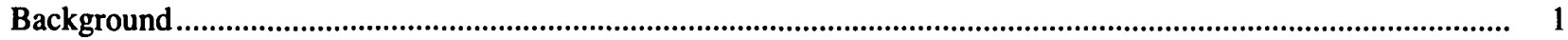

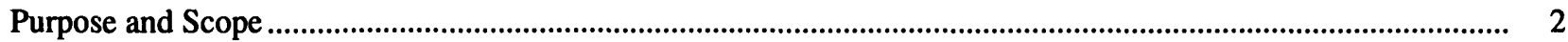

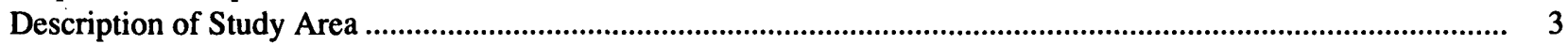

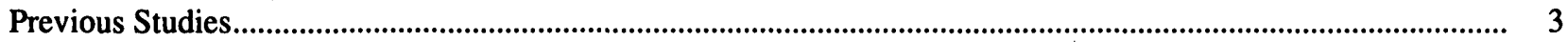

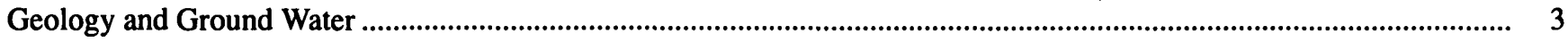

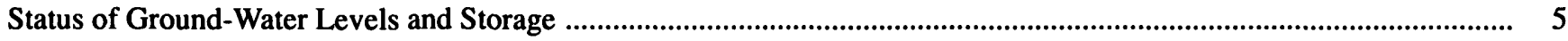

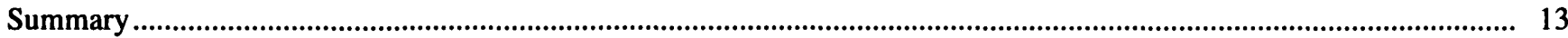

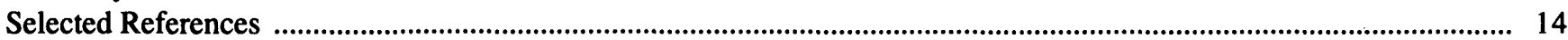

FIGURES

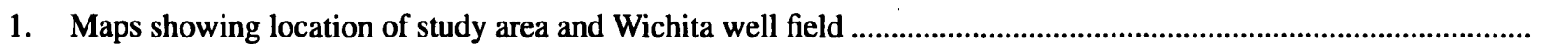

2. Graphs showing relation of precipitation, city of Wichita and agricultural water use in the study area, water-level altitudes in observation well 886 and Equus Beds aquifer storage-volume depletion in the study

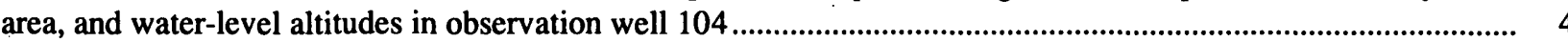

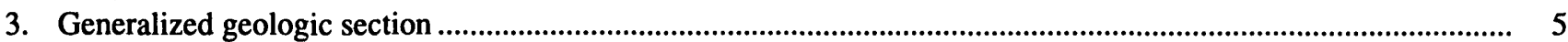

4-9. Maps showing:

4. Water-level altitudes for January 1997 in the Equus Beds aquifer in the vicinity of the Wichita well field ........ 7

5. Water-level change from August 1940 to January 1997 in the Equus Beds aquifer in the vicinity of the Wichita well field

6. Water-level change from August 1940 to April 1997 in the Equus Beds aquifer in the vicinity of the Wichita well field

7. Water-level change from August 1940 to July 1997 in the Equus Beds aquifer in the vicinity of the Wichita well field.

8. Water-level change from August 1940 to October 1997 in the Equus Beds aquifer in the vicinity of the Wichita well field

9. Water-level change between January 1993 and January 1997 in the Equus Beds aquifer in the vicinity of the Wichita well field

Graph showing areas of water-level declines in the Equus Beds aquifer in the Wichita well field area, 1997, and storage-volume depletions from August 1940 


\section{CONVERSION FACTORS AND VERTICAL DATUM}

\begin{tabular}{rcl}
\hline Multiply & \multicolumn{1}{c}{ By } & To obtain \\
\hline acre-foot & 1,233 & cubic meter \\
acre-foot per year & 1,223 & cubic meter per year \\
foot & 0.3048 & meter \\
inch & 2.54 & centimeter \\
inch per year & 2.54 & centimeter per year \\
mile & 1.609 & kilometer \\
square mile & 2.590 & square kilometer \\
\hline
\end{tabular}

Temperature can be converted to degrees Celsius $\left({ }^{\circ} \mathrm{C}\right)$ or degrees Fahrenheit $\left({ }^{\circ} \mathrm{F}\right)$ by the equations:

$$
\begin{aligned}
& { }^{\circ} \mathrm{C}=5 / 9\left({ }^{\circ} \mathrm{F}-32\right), \\
& { }^{\circ} \mathrm{F}=9 / 5\left({ }^{\circ} \mathrm{C}\right)+32 .
\end{aligned}
$$

Sea level: In this report, "sea level" refers to the National Geodetic Vertical Datum of 1929-a geodetic datum derived from a general adjustment of the first-order level nets of the United States and Canada, formerly called Sea Level Datum of 1929. 


\title{
Status of Ground-Water Levels and Storage in the Wichita Well Field Area, South-Central Kansas, 1997
}

\author{
By Walter R. Aucott, Nathan C. Myers, and Barbara J. Dague
}

\begin{abstract}
The Wichita well field was developed in the Equus Beds aquifer northwest of Wichita, Kansas, to supply water to the city. On September 1, 1940 , the city began pumping from 25 wells in the well field. Ground-water pumping from the well field caused water levels to decline over a large part of the study area. In addition, nearby agricultural pumpage increased greatly in the 1970s and 1980 s and has contributed to declining water levels in the study area.

During 1997, the direction of ground-water flow in the Equus Beds aquifer in the study area remained generally from west to east as has been the case since prior to development of the aquifer. The shape of the water-level-decline contours in 1997 also is similar to recent past years. The maximum water-level decline in 1997 since August 1940 was 31.74 feet in April near the center of the well field. The water levels in most wells varied only a few feet during 1997 . Aquifer storage-volume depletions in 1997 continued to recover from maximum depletions in January 1993. Minimum storage-volume depletions in 1997 occurred in October. Increasing water levels, due to the beginning of operations at the Halstead recharge demonstration site, are evident in wells near that site.
\end{abstract}

\section{INTRODUCTION}

\section{Background}

The Wichita well field was developed in the Equus Beds aquifer to supply water to the city of Wichita (fig. 1). On September 1, 1940, pumping began from 25 wells in the well field (Stramel, 1956). By 1959, there were 55 wells in use in the well field (Stramel, 1967). Ground-water pumpage from the well field has caused water levels to decline over a large area. Much of the water-level decline occurred from 1940 to about 1956 (Stramel, 1956). Ground-water withdrawals for irrigation in the Wichita well field area also increased greatly in the 1970s and 1980s and contributed to the water-level decline (Myers and others, 1996; Aucott and Myers, in press). Although most of the waterlevel declines can be attributed to ground-water pumpage, climatic conditions and thus recharge to the Equus Beds aquifer also have affected ground-water levels.

In 1965 the city of Wichita began using water from Cheney Reservoir (Stramel, 1967) in addition to water from the Equus Beds aquifer. Since 1995 (Warren and others, 1995), the city of Wichita, in cooperation with Equus Beds Groundwater Management District No. 2, Bureau of Reclamation, U.S. Geological Survey, U.S. Environmental Protection Agency, Kansas State agencies, Burns and McDonnell Engineering Consultants, and Mid-Kansas Engineering Consultants, have been investigating the possibility of artificial ground-water recharge in the well field area to meet future needs and to protect the aquifer from saltwater intrusion from the Burrton area. Because of the social and economic importance of ground-water resources and because of the changes that artificial recharge is expected to bring to the aquifer, the city of Wichita entered into a cooperative agreement with the U.S. Geological Survey (USGS) to document historical hydrologic conditions, their changes, and causes, in the Wichita well field area; to develop a baseline condition for evaluating the effects of artificial recharge on ground-water levels in the aquifer; and to annually review changes in the ground-water system. 


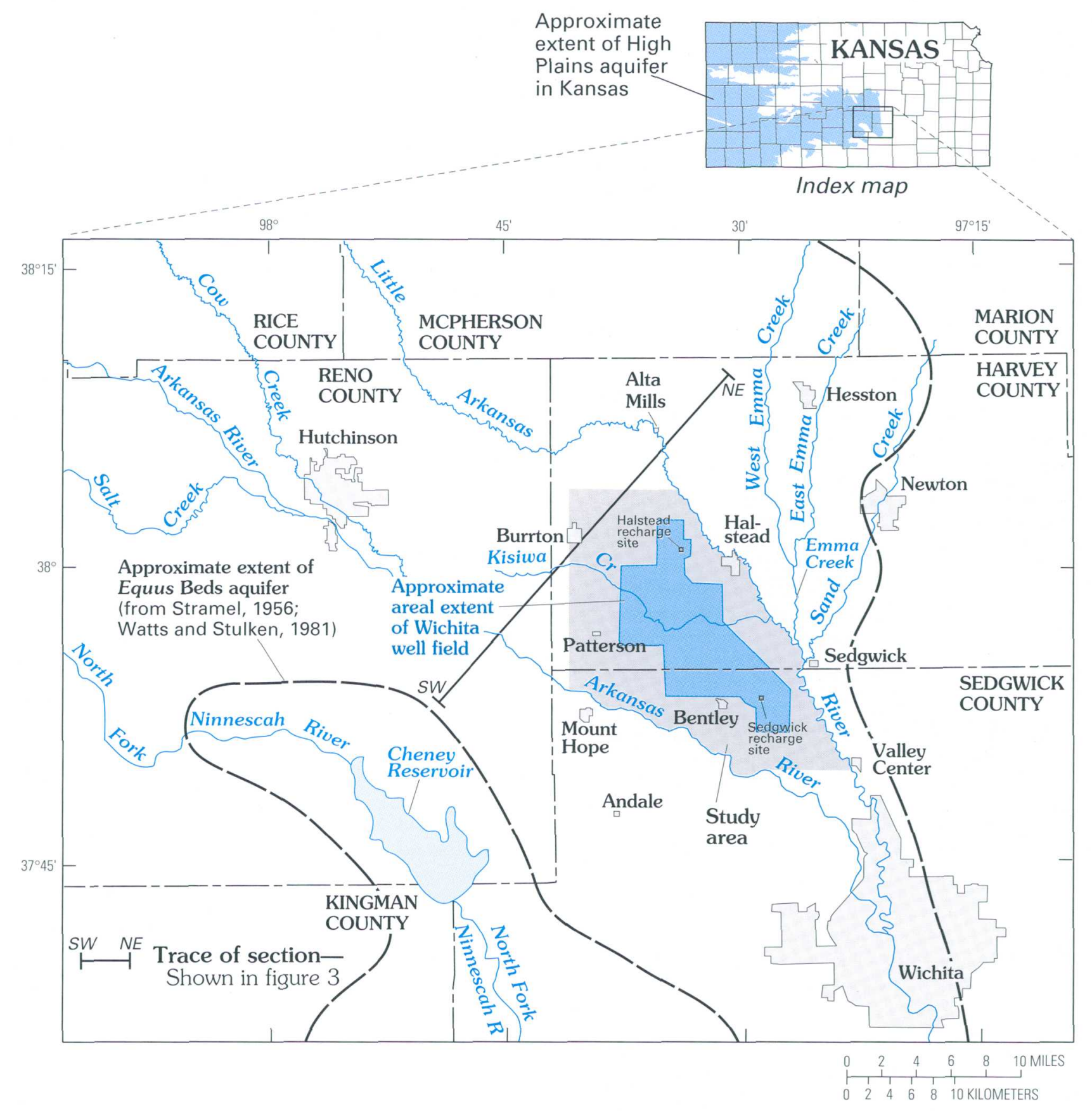

Figure 1. Location of study area and Wichita well field.

The USGS and the city of Wichita have worked cooperatively for many years in evaluating the groundwater system and the interaction with streams in the area to further the understanding of hydrologic systems and to provide information to improve local decision making.

\section{Purpose and Scope}

The purpose of this report is to present groundwater-level and storage changes in the Wichita well field area during 1997 as compared with predevelopment ground-water levels. Maps of ground-waterlevel measurements and water-level changes are presented. Two hydrographs of ground-water levels were 
selected to show historical water-level variations. Historical water-use information also is presented.

\section{Description of Study Area}

The study area (fig. 1) includes 165 square miles and is located in Harvey and Sedgwick Counties, northwest of Wichita, Kansas. It is bounded to the southwest by the Arkansas River and to the northeast by the Little Arkansas River. The Wichita well field covers 55 square miles and is located within the study area.

South-central Kansas has a continental climate that is characterized by large variations in seasonal temperatures, moderate precipitation, and windy conditions. Seasonal temperatures range from daily averages of $30.6^{\circ} \mathrm{F}$ in January to $79.6^{\circ} \mathrm{F}$ in July for 1961-90 (National Oceanic and Atmospheric Administration, 1996). Mean annual precipitation at weather stations near the study area (at Hutchinson, Mount Hope, Newton, Sedgwick, and Wichita) is 31.06 inches for 1940-96 (National Oceanic and Atmospheric Administration, 1997) (fig. 2A). Most of this precipitation occurs during spring and summer.

The study area lies in the Arkansas River section of the Central Lowlands physiographic province (Schoewe, 1949). There is very little topographic relief in the study area. For the most part, the land surface slopes gently toward the major streams in the area.

\section{Previous Studies}

Water-level data have been collected by the city of Wichita in the study area since 1940 and are on file with the USGS in Lawrence, Kansas. Water-level data have been collected in the Equus Beds aquifer by the Equus Beds Groundwater Management District No. 2, and water-level change maps have been published in their newsletter (Equus Beds Groundwater Management District No. 2, 1995). Annual waterlevel data for the High Plains aquifer (fig. 1), which includes the Equus Beds aquifer, have been collected by the Kansas Department of Agriculture (Division of Water Resources), USGS, and the Kansas Geological Survey, and are on file with the USGS in Lawrence, Kansas. These annual data have also been compiled by Schloss and others (1997) and mapped by McGuire and Sharpe (1997).
Williams and Lohman (1949) and Stramel (1956, 1967) have published water-level and water-leveldecline maps for the study area. Myers and others (1996) evaluated the hydrologic interaction between the Arkansas River and the Equus Beds aquifer in the study area. Ross and others (1997) noted the increase in water levels from 1993-97 in the Equus Beds aquifer and attributed them largely to decreases in withdrawals by the city of Wichita.

\section{GEOLOGY AND GROUND WATER}

Quaternary deposits occur throughout the study area primarily as alluvial deposits. These alluvial deposits, known locally as the Equus beds, are as much as $\mathbf{2 5 0}$ feet thick in the study area (fig. 3). The Equus beds consist primarily of sand and gravel interbedded with clay or silt but locally may consist primarily of clay with thin sand and gravel layers (Lane and Miller, 1965a; Myers and others, 1996). The middle part of the deposits generally has more finegrained material than the lower and upper parts (Lane and Miller, 1965b; Myers and others, 1996).

The Wellington Formation underlies the Quaternary deposits and is about 700 feet thick (Bayne, 1956). The Wellington Formation is composed of three members - the lower anhydrite member, about 200 feet thick; the Hutchinson Salt Member, about 300 feet thick; and the upper shale member, about 200 feet thick (Bayne, 1956). Dissolution of the Hutchinson Salt Member has resulted in subsidence of the overlying upper shale member, formation of low areas in the bedrock surface, and concurrent accumulation of alluvial deposits that now comprise the Equus beds (fig. 3) (Myers and others, 1996).

The Equus Beds aquifer is the easternmost extension of the High Plains aquifer in Kansas. The extent of the Equus Beds aquifer is delineated in figure 1 as defined by Stramel (1956). Some more recent regional studies (Watts and Stullken, 1985) have limited the areal extent to north and west of Wichita, but still include the Equus Beds aquifer in all of the study area. The Equus beds are an important source of ground water because of the generally shallow depth to the water table, the large saturated thickness, and the generally good quality water. Near the Arkansas River, the water table may be as little as 10 feet below land surface. Farther from the river and near the Little Arkansas River, the water table is at a greater depth below land surface, depending on the altitude of the 

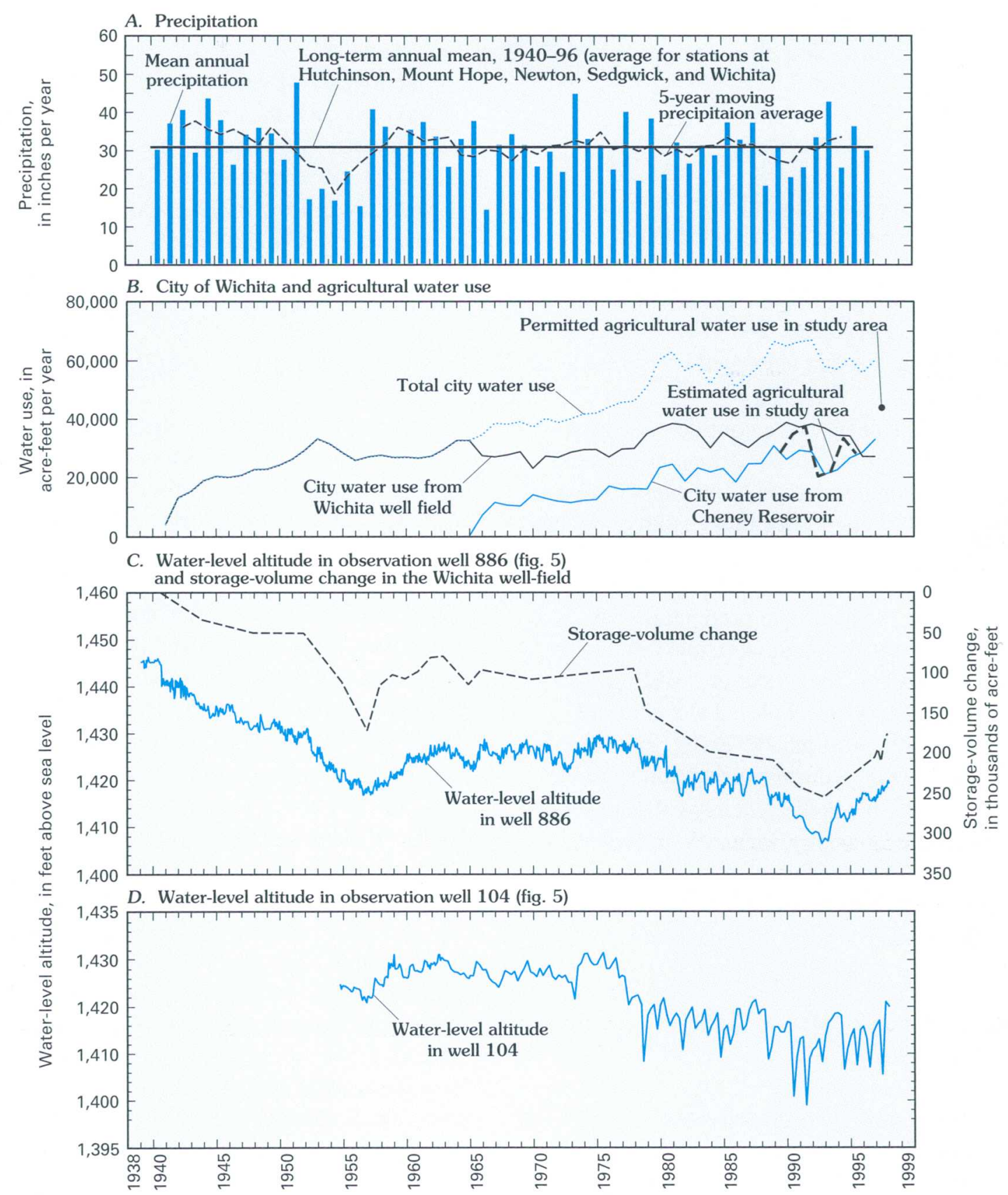

Figure 2. Relation of $(A)$ precipitation, $(B)$ city of Wichita and agricultural water use in the study area, (C) water-level altitudes in observation well 886 and Equus Beds aquifer storage-volume depletion in the study area, and $(D)$ water-level altitudes in observation well 104. Source: $(A)$ data from National Oceanic and Atmospheric Administration (1997); (B) data from Stramel (1956, 1967), Gerald T. Blain (city of Wichita, written commun., 1997) and from data on file with U.S. Geological Survey, Lawrence, Kansas; (D) data on file with the U.S. Geological Survey, Lawrence, Kansas.

land surface and the amount of water-level decline that has been caused by ground-water withdrawals. The maximum saturated thickness of the Equus Beds aquifer within the study area, almost 250 feet, is near the course of the Arkansas River and corresponds to the lowest areas of the underlying bedrock surface (fig. 3). The Wellington Formation acts as a confining unit underlying the Equus Beds aquifer. 


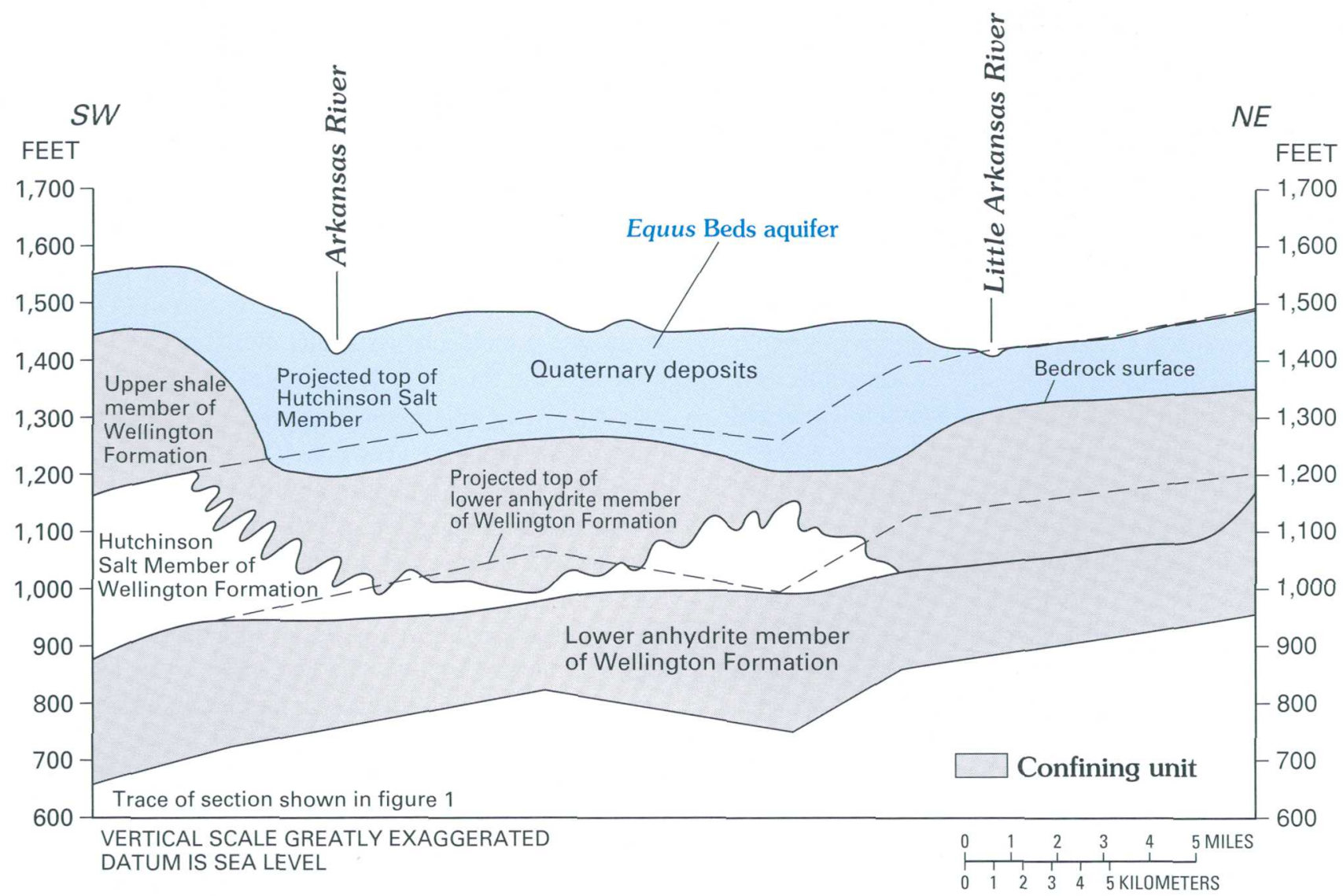

Figure 3. Generalized geologic section (from Leonard and Kleinschmidt, 1976; Myers and others, 1996).

\section{STATUS OF GROUND-WATER LEVELS AND STORAGE}

Prior to pumpage from the Wichita well field in 1940, near-predevelopment conditions existed for the Equus Beds aquifer in the study area (Williams and Lohman, 1949; Aucott and Myers, in press). Ground water flowed generally west to east and discharged to the Little Arkansas River prior to development.

Ground-water-level declines can result from pumpage and from decreased recharge resulting from less-than-average precipitation as well as other factors. Figure $2 A$ indicates annual, average, and 5-year moving average precipitation data for long-term stations in the vicinity of the study area. Droughts, such as occurred in 1952-56 and 1988-92, tend to decrease the amount of recharge available and increase the demand for and thus withdrawals of ground water, resulting in increased water-level declines.

Since 1940, ground-water pumpage for the city of Wichita and later for agricultural uses has been significant (fig. $2 B$ ). City of Wichita pumpage, which began in 1940 , increased steadily into the early 1950 s and then was relatively constant until the mid-1970s. City pumpage increased sporadically from the late $1970 \mathrm{~s}$ through the early 1990s in response to increased demand and droughts and has since decreased due to the increasing reliance of the city on Cheney Reservoir as a water-supply source. Agricultural withdrawals were relatively small until the early 1970 s but have increased rapidly since (Myers and others, 1996). Agricultural water-use amounts reported prior to the early 1990 s are not plotted in figure $2 B$ because of ongoing data-verification considerations. Estimated agricultural water use in 1997 was less than what is permitted (fig. 2). Thus, agricultural water use could increase in the study area during dry years.

The hydrograph from observaton well 886 (fig. $2 C$ ) serves as a descriptor of historical water-level changes in the area of maximum water-level decline in the well field. Four time periods are noteworthy. The period 1940-57 represents the initial water-leveldecline phase when wells were first installed in the Wichita well field and withdrawals began. Accelerated declines during the mid-1950s coincide with drought conditions. A general equilibrium was maintained between 1958 and 1977. Water levels responded to seasonal pumping stresses, but no long- 
term declines occurred. Between 1978 and 1992, another phase of water-level declines occurred, climaxing with lows of record for most wells in 1991-93. These lows coincided with the 1988-92 drought and were caused by increased withdrawals and decreased recharge resulting from drought conditions. A general water-level rise began in the study area in the Equus Beds aquifer in 1993 (Aucott and Myers, in press). A principal factor in this water-level rise was decreased ground-water withdrawals that accompanied increased use of Cheney Reservoir as a water-supply source for the city of Wichita (Ross and others, 1997). This shifting of water sources was a part of the city of Wichita's Integrated Resource Plan (IRP) (Warren and others, 1995).

The hydrograph of well 104 (fig. 2D) is a representative description of irrigation effects outside of the well field area. Water levels decreased in well 104 more than 10 feet in the 1970s (fig. 2D) in response to increased irrigation withdrawals. Since then, water levels have decreased somewhat and have exhibited much greater seasonal changes in response to seasonal irrigation withdrawals. The minimum water level occurred in the summer of 1991 in well 104 in response to the 1988-92 drought (fig. 2D).

During 1997, the direction of flow in the Equus Beds aquifer in the study area remained generally from west to east (fig. 4) as has been the case in most areas since prior to development. However, there were some changes in flow direction in the area between the well field and the Little Arkansas River (fig. 4).

The shape of the water-level-decline contours in 1997 (figs. 5-8) is similar to recent past years (Aucott and Myers, in press). These water-level change maps were constructed using August 1940 measurements where they existed, primarily near city wells $1-25$, and a few measurements from September 1940 for some wells in the western part of the study area. Where no 1940 measurements existed, values were interpolated from the August 1940 water-level contour map (Aucott and Myers, in press). The maximum waterlevel decline in 1997 since August 1940 was 31.74 feet at well 17 in April (fig. 6). The greatest variations in water levels during 1997 occurred in the northwest part of the study area near wells 102, 104, and 3036, with the greatest declines occurring in July (figs. 5-8). These declines are probably a result of irrigation pumpage and may have been accentuated by semiconfined aquifer conditions in this part of the study area. Water levels in most wells in the study area varied only a few feet during 1997 . Declines in the center of well field pumpage were greatest in January and less in later months, reflecting the trend since 1993 of decreased city pumpage. The trend of waterlevel rises since some of the lowest water levels occurred in the well field in January 1993 continued in 1997. Water-level rises were as much as 11.10 feet in well 12 in the center of well-field pumpage. Figure 9 indicates that water-level rises that occurred in the study area are closely associated with the city well field area and thus with decreases in city withdrawals.

The city of Wichita is investigating the potential for artificial recharge at two sites near Halstead and Sedgwick (fig. 1). Operation of the Halstead recharge demonstration site began in September 1997. Water levels at the nearest well to the Halstead recharge site used in this report (observation well near city supply well 4) increased more than 2 feet between July and October measurements, whereas water levels in other nearby wells used in this report declined, indicating some effects from the recharge site. A 20-foot rise in water level was noted in an observation well closer to the recharge site shortly after recharge began (David Stous, Burns and McDonnell, written commun., 1997).

Changes in storage since 1940 tended to mirror water-level changes in the most severely affected wells as exemplified by figure $2 C$. Changes in storage were represented as areas inside water-level-decline contours for selected time periods since August 1940 and were computed as changes in storage volume inside the study area and inside the well field boundary (fig. 10). Specific yield was assumed to be 0.2 as used by Stramel (1956). Storage-volume depletions have continued to recover from maximums in January 1993 (Aucott and Myers, in press). Storage-volume depletions were less throughout 1997 than in October 1996. Maximum storage-volume depletions in 1997 occurred in July in the study area in response to irrigation pumpage and in January within the well field boundary, whereas minimum depletions occurred in October. Water-level declines at individual wells such as observation well 886 are important for indicating changes at a specific location and are suggestive of the effects near that location, such as dewatered shallow wells or increased pumping costs to lift water from greater depths. Changes in storage volume are a better measure of the overall effect on the aquifer and represent a decrease (or increase) in the ground-water resource available for use. 


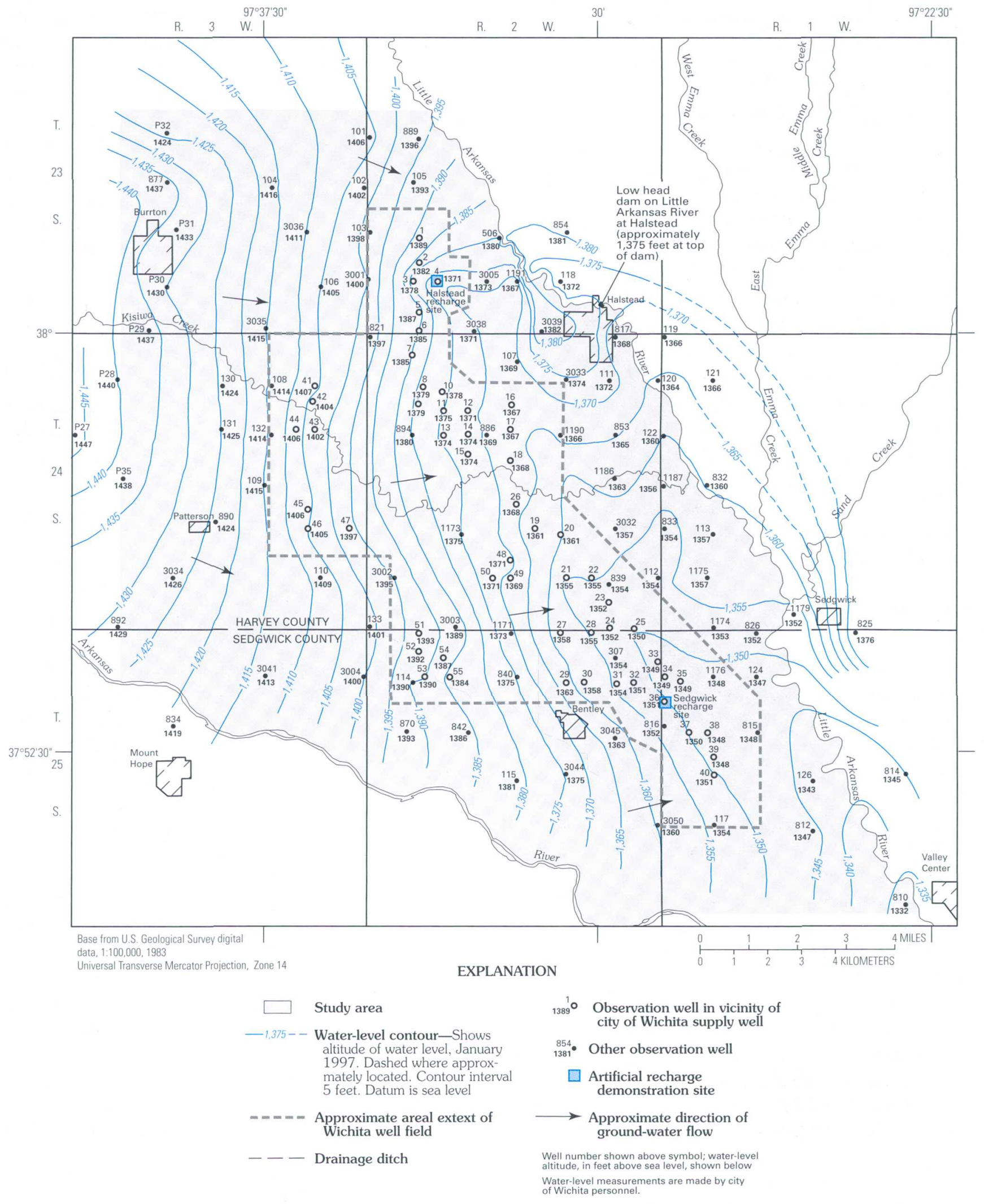

Figure 4. Water-level altitudes for January 1997 in the Equus Beds aquifer in the vicinity of the Wichita well field. 


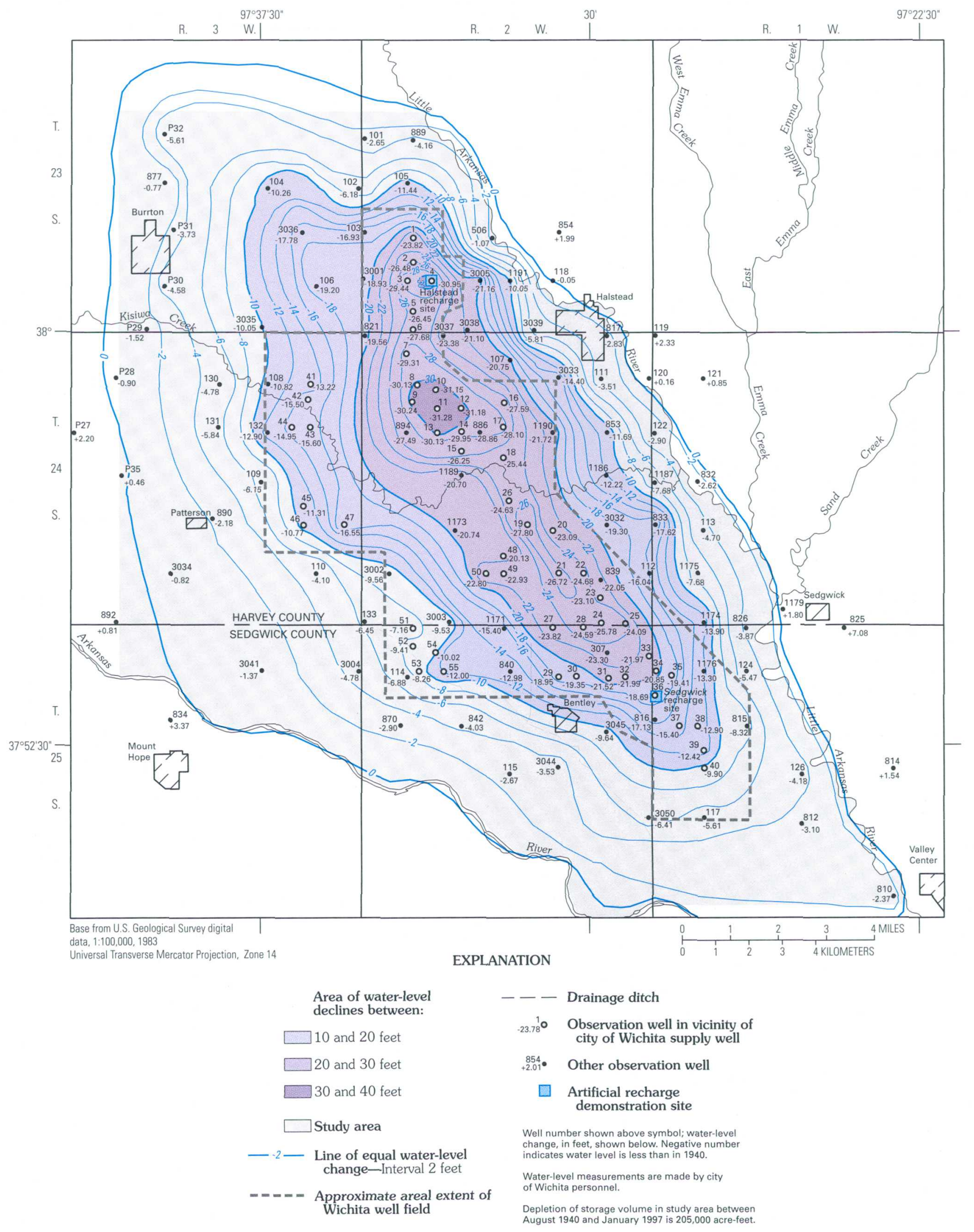

Figure 5. Water-level change from August 1940 to January 1997 in the Equus Beds aquifer in the vicinity of the Wichita well field. 


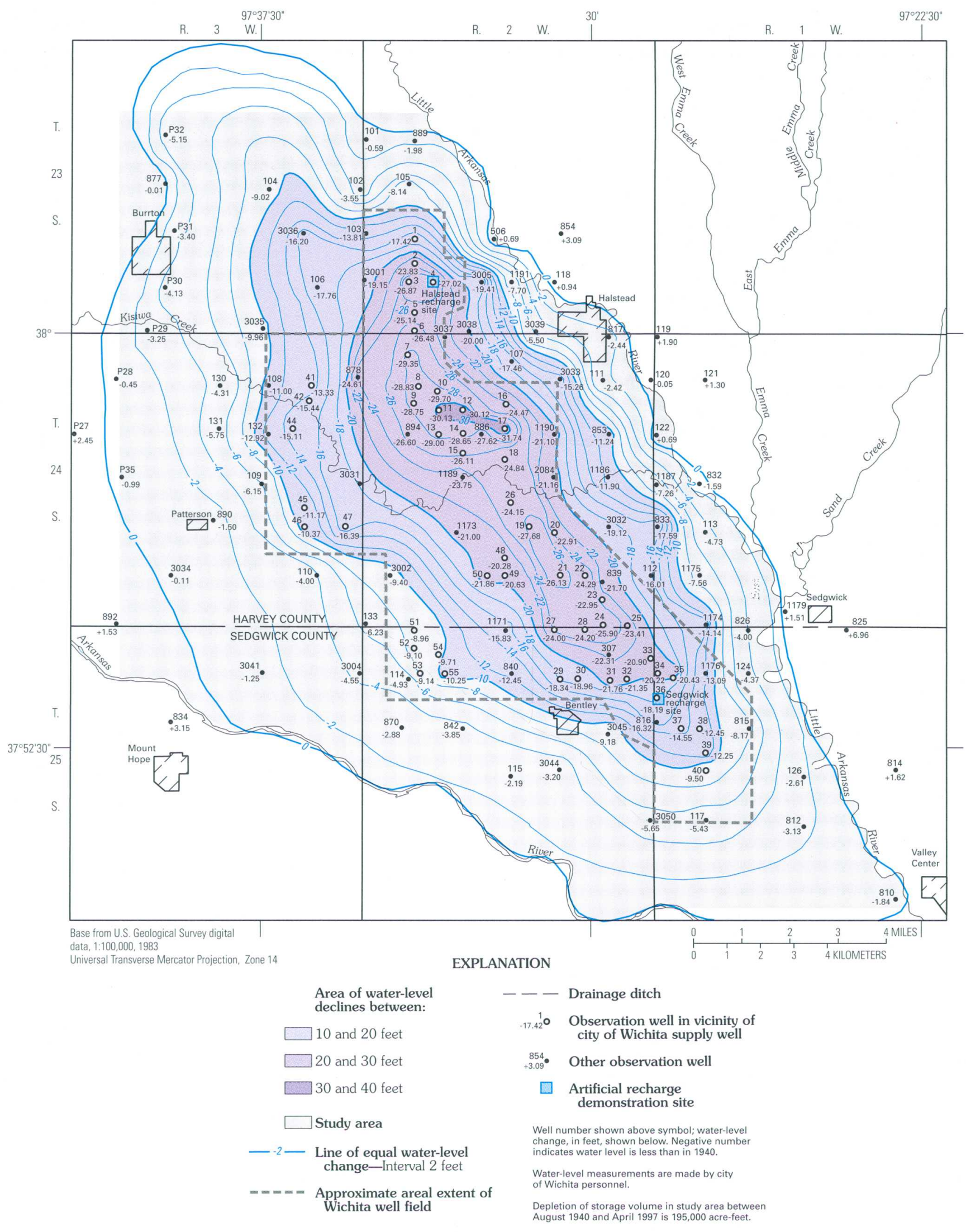

Figure 6. Water-level change from August 1940 to April 1997 in the Equus Beds aquifer in the vicinity of the Wichita well field. 


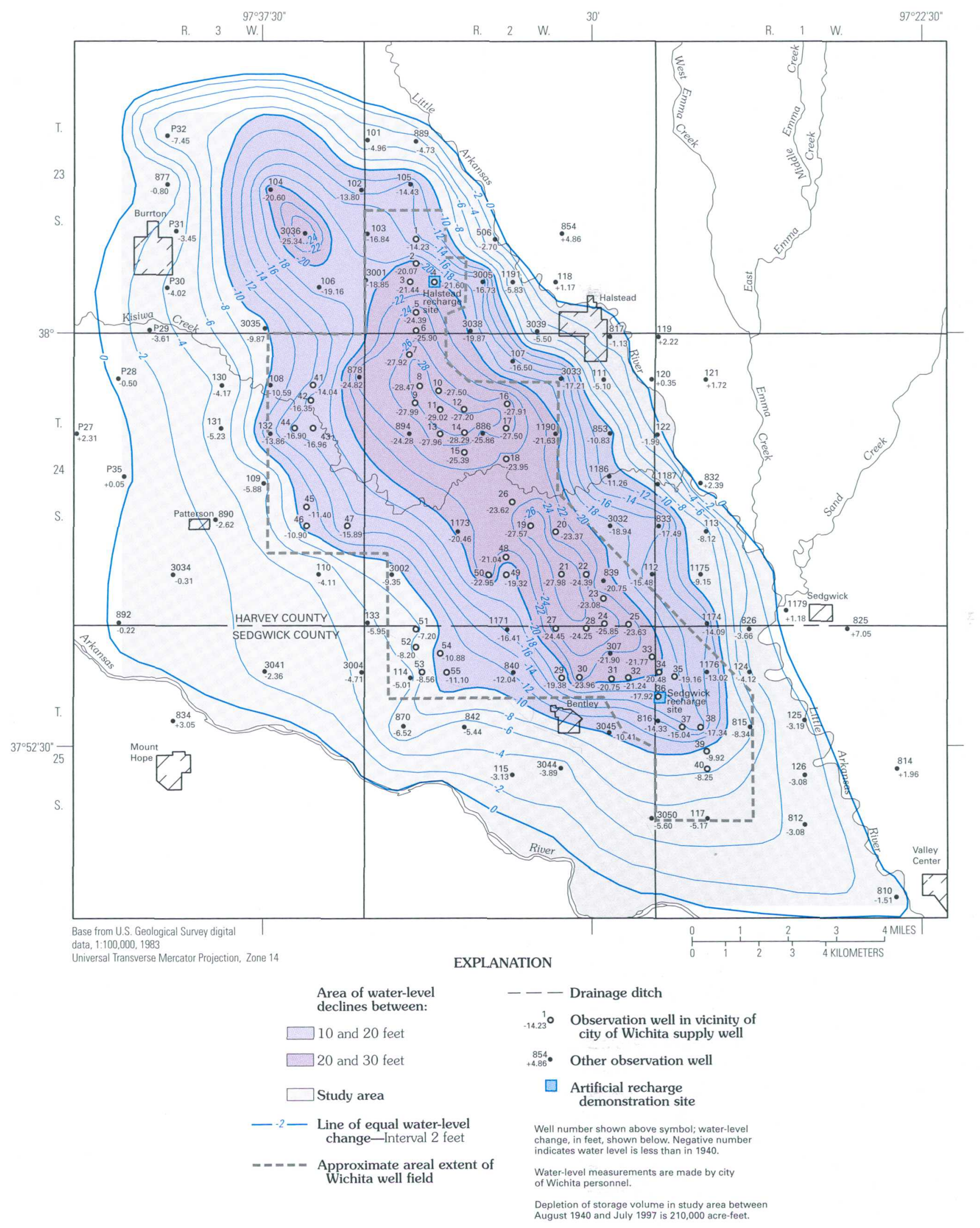

Figure 7. Water-level change from August 1940 to July 1997 in the Equus Beds aquifer in the vicinity of the Wichita well field. 


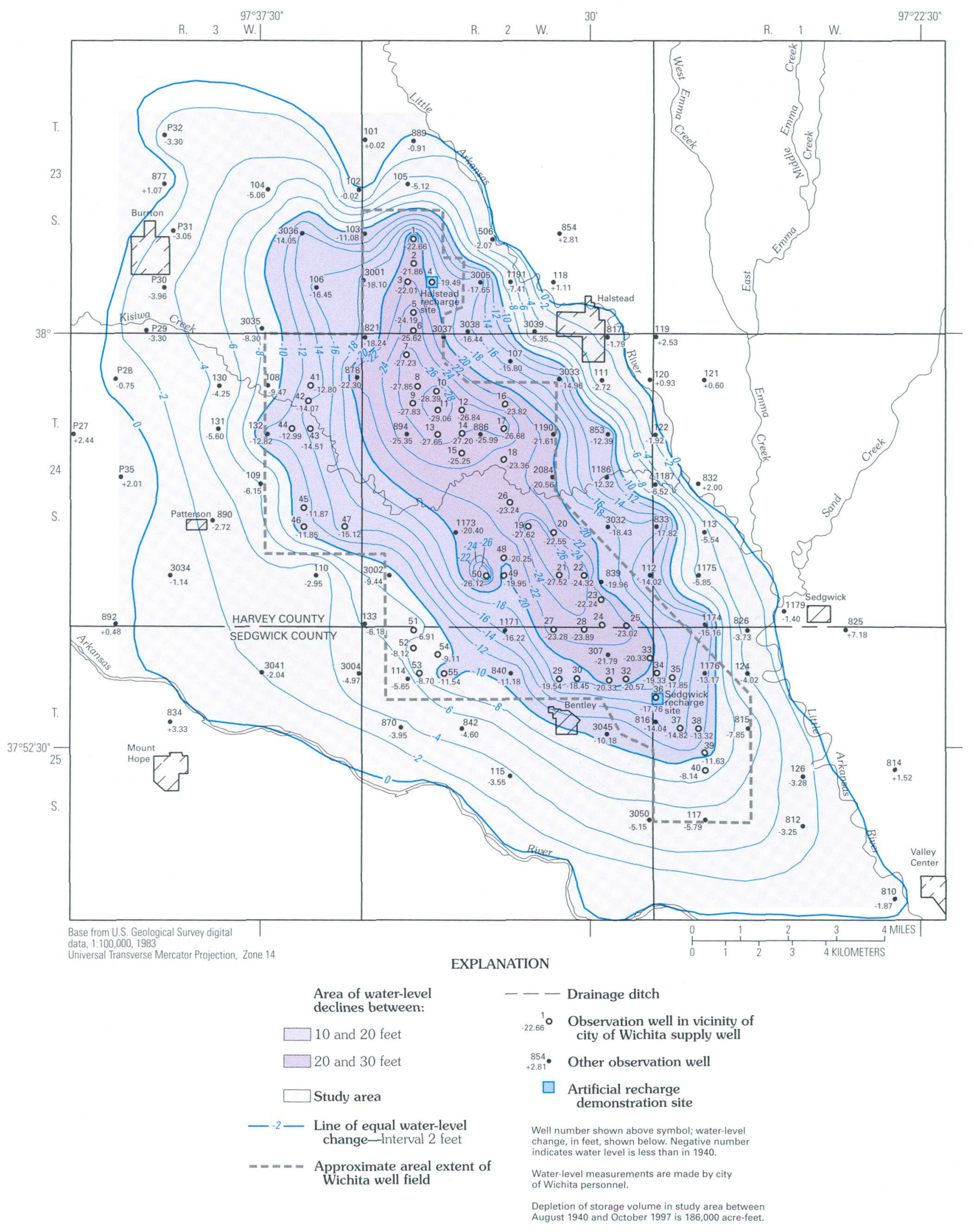

Figure 8. Water-level change from August 1940 to October 1997 in the Equus Beds aquifer in the vicinity of the Wichita well field. 


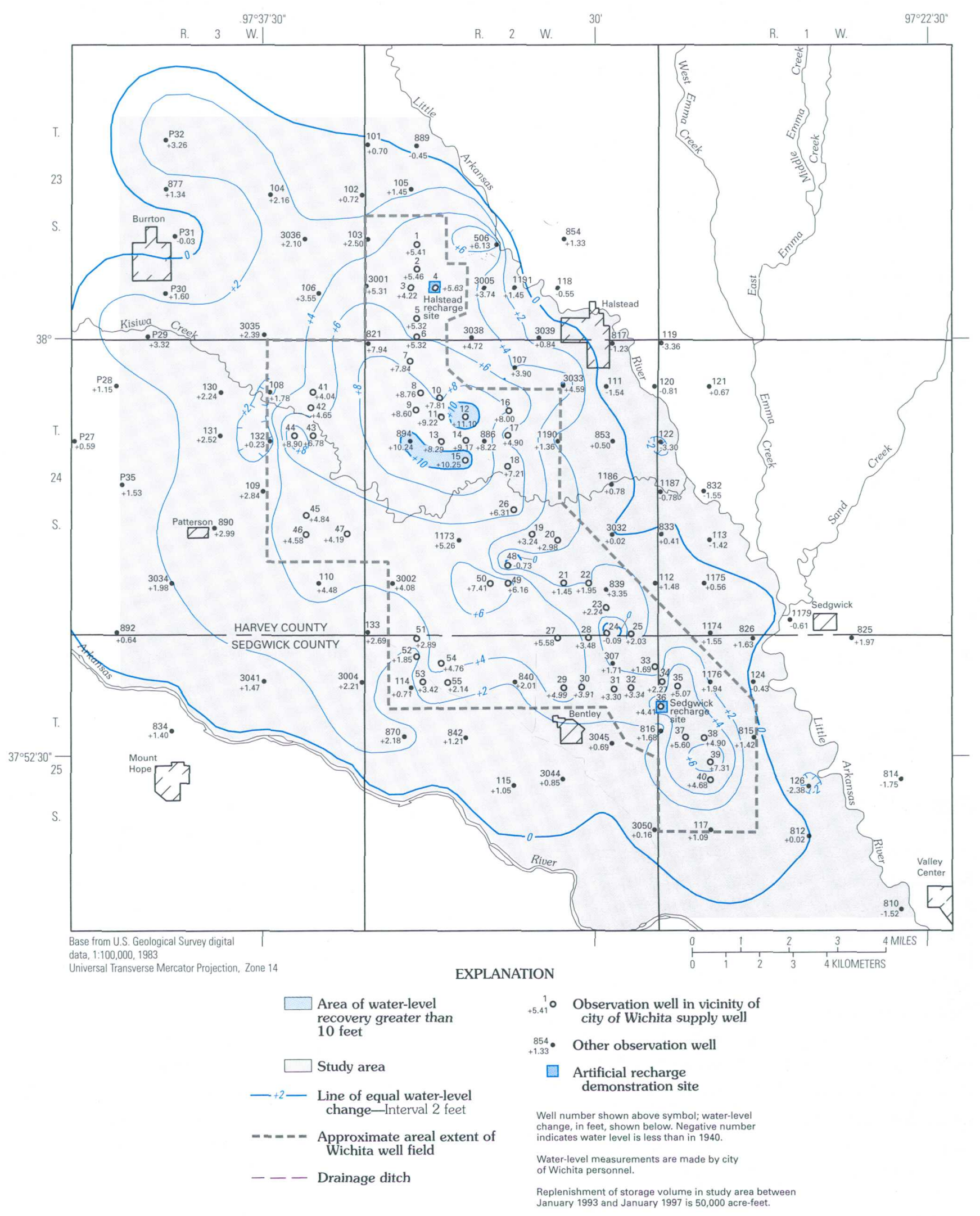

Figure 9. Water-level change between January 1993 and January 1997 in the Equus Beds aquifer in the vicinity of the Wichita well field. 


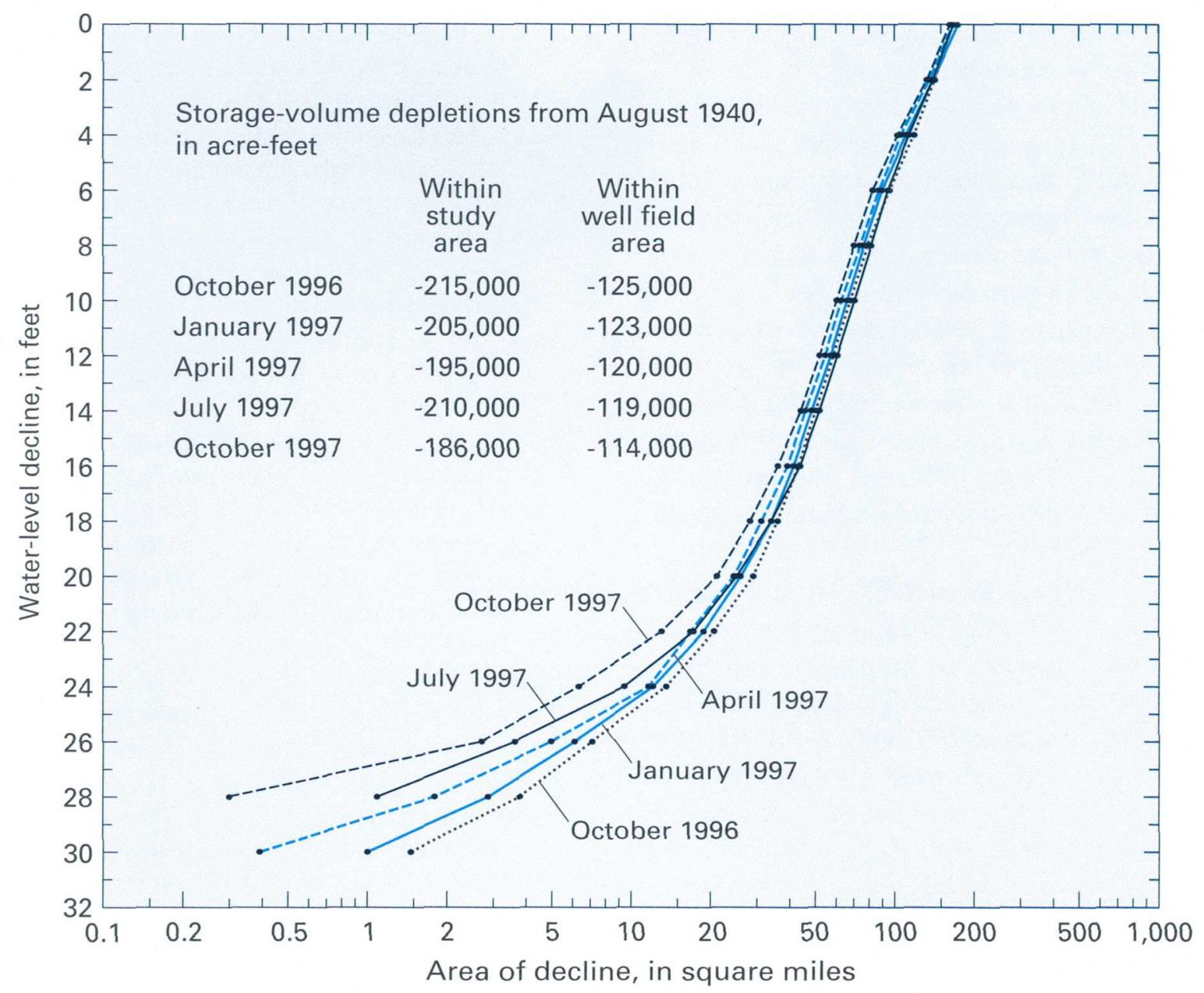

Figure 10. Areas of water-level declines in the Equus Beds aquifer in the Wichita well field area, 1997, and storage-volume depletions from August 1940.

\section{SUMMARY}

The Wichita well field was developed in the Equus Beds aquifer to supply water to the city of Wichita, Kansas. On September 1, 1940, the city began pumping from 25 wells in the well field, and by 1959 there were 55 wells in use in the well field. Ground-water pumpage from the well field has caused water levels to decline over a large part of the study area. In addition, nearby agricultural pumpage increased greatly in the 1970s and 1980s and has contributed to declining water levels in the study area. Although most of the water-level declines can be attributed to ground-water pumping, climatic conditions, and thus recharge to the Equus Beds aquifer, also have affected ground-water levels. In addition to water from the Equus Beds aquifer, the city of Wichita began using water from Cheney Reservoir in 1965, and since 1995 the city has been investigating the possibility of artificial ground-water recharge in the well-field area to meet future needs and to protect the aquifer from saltwater intrusion from near Burrton.

Quaternary alluvial deposits, known as the Equus beds, are as much as 250 feet thick in the study area and consist primarily of sand and gravel interbedded with clay or silt but locally may consist primarily of clay with thin sand and gravel layers. The Wellington Formation underlies the Quaternary deposits, forming the bedrock confining unit below these deposits. Dissolution of the Hutchinson Salt Member, the middle member of the Wellington Formation, has resulted in subsidence of the overlying upper shale member of the Wellington Formation, the formation of low areas in the bedrock surface, and the concurrent accumulation of the alluvial deposits that now comprise the Equus beds.

A ground-water hydrograph near the center of the Wichita well field shows four noteworthy time 
periods: 1940-57 represents the initial water-leveldecline phase when withdrawals began in the well field and includes a period of accelerated declines in the mid-1950s coinciding with drought conditions; a general equilibrium in water levels during 1958-77; another phase of water-level declines during 1978-92, partially coinciding with a drought, climaxing with lows of record for most wells in 1991-93; and a waterlevel rise that began in 1993. A ground-water hydrograph in the study area but outside of the well field area shows mainly the effects of irrigation pumping. This hydrograph indicates that water levels decreased more than 10 feet in the 1970s and since have shown greater seasonal variability and a minimum water level in the summer of 1991.

During 1997, the direction of ground-water flow in the Equus Beds aquifer in the study area generally was from west to east as has been the case since prior to development of the aquifer. The shape of the waterlevel-decline contours in 1997 also is similar to recent past years. The maximum water-level decline in 1997 since August 1940 was 31.74 feet in April near the center of the well field. The water levels in most wells varied only a few feet during 1997 . Aquifer storagevolume depletions in 1997 continued to recover from maximum declines in January 1993. Minimum storage-volume depletions in 1997 occurred in October. Increasing water levels, due to the beginning of operations at the Halstead recharge demonstration site in September 1997, are evident in wells near that site. Water-level declines at individual wells are indicative of changes at a specific location and suggest effects near that location, such as dewatered shallow wells or increased pumping costs to lift water from greater depths. Changes in storage volume are a better measure of the overall effect of pumping on the aquifer and represent a decrease (or increase) in the groundwater resource available for use.

\section{SELECTED REFERENCES}

Aucott, W.R., and Myers, N.C., in press, Changes in ground-water levels and storage in the Wichita well field area, south-central Kansas, 1940-98: U.S. Geological Survey Water-Resources Investigations Report.

Bayne, C.K., 1956, Geology and ground-water resources of Reno County, Kansas: Kansas Geological Survey Bulletin $120,130 \mathrm{p}$.
Bevans, H.E., 1988, Water resources of Sedgwick County, Kansas: U.S. Geological Survey Water-Resources Investigations Report 88-4225, 119 p.

Equus Beds Groundwater Management District No. 2, 1995, Equus Beds Groundwater Management District No. 2 Management Program: Halstead, Kansas, 99 p.

Kansas Department of Agriculture, Division of Water Resources, and Kansas Water Office, 1990-96, Kansas irrigation water use: Topeka, Kansas [annual report].

Lane, C.W., and Miller, D.E., 1965a, Geohydrology of Sedgwick County, Kansas: Kansas Geological Survey Bulletin 176, $100 \mathrm{p}$.

1965b, Logs of wells and test holes in Sedgwick County, Kansas: Kansas Geological Survey Special Distribution Publication 22, $175 \mathrm{p}$.

Leonard, R.B., and Kleinschmidt, M.K., 1976, Saline water in the Little Arkansas River Basin area, south-central Kansas: Kansas Geological Survey Chemical Quality Series 3, $24 \mathrm{p}$.

McGuire, V.L., and Sharpe, J.B., 1997, Water-level changes in the High Plains aquifer-predevelopment to 1995: U.S. Geological Survey Water-Resources Investigations Report 97-4081, 2 sheets.

Myers, N.C., Hargadine, G.D., and Gillespie, J.D., 1996, Hydrologic and chemical interaction of the Arkansas River and the Equus Beds aquifer between Hutchinson and Wichita, south-central Kansas: U.S. Geological Survey Water-Resources Investigations Report 95-4191, 100 p.

National Oceanic and Atmospheric Administration, 1996, Climatological data, annual summary, Kansas, 1996: Asheville, North Carolina, v. 110, no. 13 (published annually).

1997, Monthly precipitation data for United States cooperative and National Weather Service sites: Asheville, North Carolina, National Climate Data Center, ftp ftp.ncdc.noaa.gov/pub/data/coop-precip/.

Petri, L.R., Lane, C.W., and Furness, L.W., 1964, Water resources of the Wichita area, Kansas: U.S. Geological Survey Water-Supply Paper 1499-I, 69 p.

Ross, H.C., Myers, N.C., and Aucott, W.R., 1997, Increased use of Cheney Reservoir for Wichita area water supply benefits Equus Beds aquifer: U.S. Geological Survey Fact Sheet FS-196-97, 2 p.

Schloss, J.A., Woods, J.J., and Macfarlane, P.A., 1997, January 1997 Kansas water-level measurements: Kansas Geological Survey Open-File Report 97-34, 69 p.

Schoewe, W.H., 1949, The geography of Kansas, part 2-Physical geography: Transactions of the Kansas Academy of Science, v. 52, no. 3, p. 261-333.

Stramel, G.J., 1956, Progress report on the ground-water hydrology of the Equus beds area, Kansas: Kansas Geological Survey Bulletin 119, part 1, 59 p. 
1967, Progress report on the ground-water hydrology of the Equus beds area, Kansas 1966: Kansas Geological Survey Bulletin 187, part 2, 27 p.

Warren, D.R., Blain, G.T., Shorney, F.L., and Klein, L.J., 1995, IRP - a case study from Kansas: Journal of the American Water Works Association, June 1995, p. 57-71.
Watts, K.R., and Stullken, L.E., 1985, Generalized configuration of the base of the High Plains aquifer in Kansas: U.S. Geological Survey Open-File Report 81-344, 1 sheet, scale 1:500,000.

Williams, C.C., and Lohman, S.W., 1949, Geology and

- ground-water resources of a part of south-central Kansas, with special reference to the Wichita municipal water supply: Kansas Geological Survey Bulletin 79, $455 \mathrm{p}$. 
¿ U.S. GOVERNMENT PRINTING OFFICE: $1998-657-505$ 
은

궁

ํㅗㄹ

$\sum$

ฐิ

בั้

ธัง

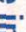

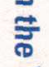

ํ.

ज्ञ

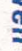

곰

จ

es

$\stackrel{0}{F}$

禺

즘

종

$\overrightarrow{0}$

 